\title{
Correction to: Does plain radiography still have a role in cases of fish bone ingestion in emergency rooms? A retrospective analysis
}

\author{
Tzu-Chi Wu ${ }^{1,2} \cdot$ Pin-Wen Huang ${ }^{1} \cdot$ Chun-Bin Tung ${ }^{1}$
}

Published online: 11 February 2021

(C) The Author(s) 2021

\section{Correction to: Emergency Radiology (2021). https://doi.org/10.1007/s10140-020-01891-1}

In the original version of this paper contains an error in Methods section. BLINDED text should be replaced with "Show Chwan Memorial Hospital". The Original article has been corrected.

Open Access This article is licensed under a Creative Commons Attribution 4.0 International License, which permits use, sharing, adaptation, distribution and reproduction in any medium or format, as long as you give appropriate credit to the original author(s) and the source, provide a link to the Creative Commons licence, and indicate if changes were made. The images or other third party material in this article are included in the article's Creative Commons licence, unless indicated otherwise in a credit line to the material. If material is not included in the article's Creative Commons licence and your intended use is not permitted by statutory regulation or exceeds the permitted use, you will need to obtain permission directly from the copyright holder. To view a copy of this licence, visit http://creativecommons.org/licenses/by/4.0/.

Publisher's note Springer Nature remains neutral with regard to jurisdictional claims in published maps and institutional affiliations.

The online version of the original article can be found at https://doi.org/ 10.1007/s10140-020-01891-1

Tzu-Chi Wu

j10062008@hotmail.com

1 Department of Emergency Medicine, Show Chwan Memorial Hospital, Changhua, Taiwan

2 Graduate Institute of Technology Management, National Chung Hsing University, Taichung, Taiwan 